\title{
A Comparative Study of Awareness of Breast Feeding Among Pregnant And Lactating women in Nalanda District (Bihar)
}

\author{
Dr. Awadhesh Kumar Sinha ${ }^{1}$, Dr. Avinash Kumar Sahay ${ }^{2}$ \\ ${ }^{I M . D .(P e d) \text { Ph.D(Ped) }}$ Assistant Professor, Department Of Paediatrics, Verdhman Institute Of Medical Sciences, \\ Pawapuri, Nalanda, Bihar. \\ ${ }^{2 M . D .(P e d)}$ Associate Professor, Department Of Paediatrics, Verdhman Institute Of Medical Sciences, Pawapuri, \\ Nalanda, Bihar.
}

\begin{abstract}
Objective: To study the awareness regarding appropriate breast feeding practices and advantage of breast milk among pregnant and lactating women of both urban and rural area of Nalanda district, Bihar.

Methods: For studying awareness an interview schedule comprised of open ended question was developed and data was analyzed to see the differences in two independent proportions.

Observation: Awareness in various aspects of breast feeding practices were poor particularly among illiterate and most of the rural literate women due to widespread illiteracy and superstition. About $2 / 3^{\text {rd }}$ of educated and 1/2 of the literate of urban area knew that babies should be exclusively breast fed for six months. Both rural and urban educated opined that breast milk should be started immediately after birth and breast milk helps to protect babies from cough-cold, diarrhea and other illness, In contrast illiterate of both urban \& rural area were more aware of the fact that breast feeding should be continued as long as possible.

Conclusion: Possible reason for suboptimal breast feeding were primarily due to lack of proper information to the mothers, inadequate health support, inability of the health care provider to help mother for appropriate breast feeding practices and aggressive promotion of infant milk substitute by commercial house. For creating awareness regarding various aspect of breast feeding through interpersonal communication in hospital set up and periphery by trained health and paramedical staff is necessary. For IEC regarding protection and promoting breast feeding among general public help of mass media of communication is needed.
\end{abstract}

Keywords: Awareness, breast feeding practices, pregnant and lactating women, rural \& urban.

\section{Introduction}

The global strategy for infant and young child feeding states that breast feeding is unequalled way of providing ideal food for healthy growth and development of infant. As per the new norm (IMNCI, 1990) breast feeding should be started immediately after birth and infant should be exclusively breast fed for first six month of life. Introduction of complementary feeding from six month with continuation of breast feeding for 2 yrs or beyond is important for appropriate and healthy growth as it contains all the necessary macro and micro nutrients which provide $1 / 2$ to $1 / 3^{\text {rd }}$ of nutritional requirements between six month to two years of age. The first milk called colostrum is most suitable for the baby as it contain high concentration of protein and other nutrients. Breast milk, along with colostrum, contains various anti infective factors which protect the baby against respiratory tract infection, diarrheal diseases and other illness. Frequent sucking of breast milk causes increased production of milk from breast. Field and laboratory investigations have confirmed the traditional belief that lactation prolongs post partum amenorrhea and provide some degree of protection against pregnancy (Population Report Journal, 1981).

The status of breast feeding practices is very dismal in India as only $29 \%$ of children are breast fed within $1^{\text {st }}$ hour of birth and only $55 \%$ initiate breast feeding within $1^{\text {st }}$ day of life. More than half of new born receive pre lacteal feeds and exclusive breast feeding up to six months is only $46 \%$ (NFHS-3). Sub optimal breast feeding is important cause of under nutrition and under five mortality.

The present work has been carried out with the aim to find out as to how far the rural women were aware of advantages of breast milk and appropriate breast feeding practices in comparison to their urban counter parts and impact of major programmers related to breast feeding among them.

\section{Material And Methods}


Nalanda district situated in the Gangetic plane of Bihar State, is having a population of about 32 lakhs with $15 \%$ people residing in the urban area and $85 \%$ residing in rural area. As per senses (2011) male literacy rate in the district is $75 \%$ and female literacy rate about $53 \%$. Woman especially mothers are usual person responsible for feeding practices during infancy and childhood. Therefore, studying sample in the present study has been pregnant women and lactating mothers coming from both rural \& urban area of Nalanda District, attending the OPD and admitted in the IPD of Sadar Hospital, Biharsharif, the district headquarter of Nalanda, between July 2015 to June 2016.

For studying awareness an interview schedule was developed, which comprised of open ended and structured question on awareness of various aspects of correct and appropriate breast feeding practices and advantage of breast milk. The schedule was in Hindi, the local language and interview was done by principal investigator and associate colleague assisted by some staff nurse, Asha and Mamta in the sadar hospital, Biharsharif.

Respondents were categorized according to their literacy level into three groups-

1. Educated - Who had been at school at least for five years and could read and write fluently and understand well.

2. Literate - Schooled for less than five years and could read and write fluently or slowly and can understand.

3. Illiterate -Who could not read or write at all.

The answer given by the woman during their interview were recorded on the schedule for subsequent analysis. For comparison purposes in the study statistical test of significance were applied. Generally table was prepared for result presentation in the form of percentage distribution. Large sample test i.e. Z-test was applied to see the difference in two independent proportion. $\mathrm{P}$ value $(<0.05)$ was considered as statistically significant.

Table: Details of result of study on awareness regarding different parameters of breast feeding.

\begin{tabular}{|c|c|c|c|c|c|c|c|c|c|c|c|c|c|c|}
\hline \multirow{4}{*}{$\begin{array}{l}\text { S.N } \\
\text { o. }\end{array}$} & \multirow{4}{*}{$\begin{array}{l}\text { Parameters } \\
\text { Of Interest }\end{array}$} & \multirow{4}{*}{\begin{tabular}{|l|} 
Expecte \\
$\mathrm{d}$ \\
Correct \\
Respon \\
se
\end{tabular}} & \multicolumn{6}{|c|}{ Biharsharif (Town) Urban } & \multicolumn{6}{|c|}{ Biharsharif (Block) Rural } \\
\hline & & & \multicolumn{6}{|c|}{ Correct Response } & \multicolumn{6}{|c|}{ Correct Response } \\
\hline & & & \multicolumn{2}{|c|}{$\begin{array}{l}\text { Educated } \\
(\mathrm{N}=110)\end{array}$} & \multicolumn{2}{|c|}{$\begin{array}{l}\text { Literate } \\
(\mathrm{N}=95)\end{array}$} & \multicolumn{2}{|c|}{$\begin{array}{l}\text { Illiterate } \\
(\mathrm{N}=74)\end{array}$} & \multicolumn{2}{|c|}{$\begin{array}{l}\text { Educated } \\
(\mathrm{N}=110)\end{array}$} & \multicolumn{2}{|c|}{$\begin{array}{l}\text { Literate } \\
(\mathrm{N}=95)\end{array}$} & \multicolumn{2}{|c|}{$\begin{array}{l}\text { Illiterate } \\
(\mathrm{N}=74)\end{array}$} \\
\hline & & & $\begin{array}{l}\mathrm{N} \\
\mathrm{o}\end{array}$ & $\%$ & $\mathrm{Nc}$ & $\%$ & $\mathrm{~N}$ & $\%$ & No & $\%$ & & $\%$ & No & $\%$ \\
\hline 1. & $\begin{array}{l}\text { Till What } \\
\text { Age Babies } \\
\text { Be } \\
\text { Exclusively } \\
\text { Breast-Fed. }\end{array}$ & $\begin{array}{l}6 \\
\text { Months }\end{array}$ & 84 & 76.4 & 52 & 54.7 & 2 & 27.5 & 25 & 44. & 4 & 38.7 & 32 & 24.6 \\
\hline 2. & $\begin{array}{l}\text { Till What } \\
\text { Age Of The } \\
\text { Baby Breast } \\
\text { Feeding } \\
\text { Should Be } \\
\text { Continued? }\end{array}$ & $\begin{array}{l}\text { As } \\
\text { Long } \\
\text { As } \\
\text { Possibl } \\
\text { e }\end{array}$ & 43 & 39.1 & 45 & 47. & 6 & 83.8 & 36 & 64. & 7 & 68.8 & 118 & 90.8 \\
\hline 3. & $\begin{array}{l}\text { After } \\
\text { Birthwhen } \\
\text { The Breast } \\
\text { Feeding } \\
\text { Should Start } \\
\text { ? }\end{array}$ & $\begin{array}{l}\text { Immedia } \\
\text { tely } \\
\text { After } \\
\text { Birth }\end{array}$ & 75 & 68.2 & 43 & 45. & 2 & 29.7 & 32 & 57. & 4 & 39.6 & 32 & 24.6 \\
\hline
\end{tabular}




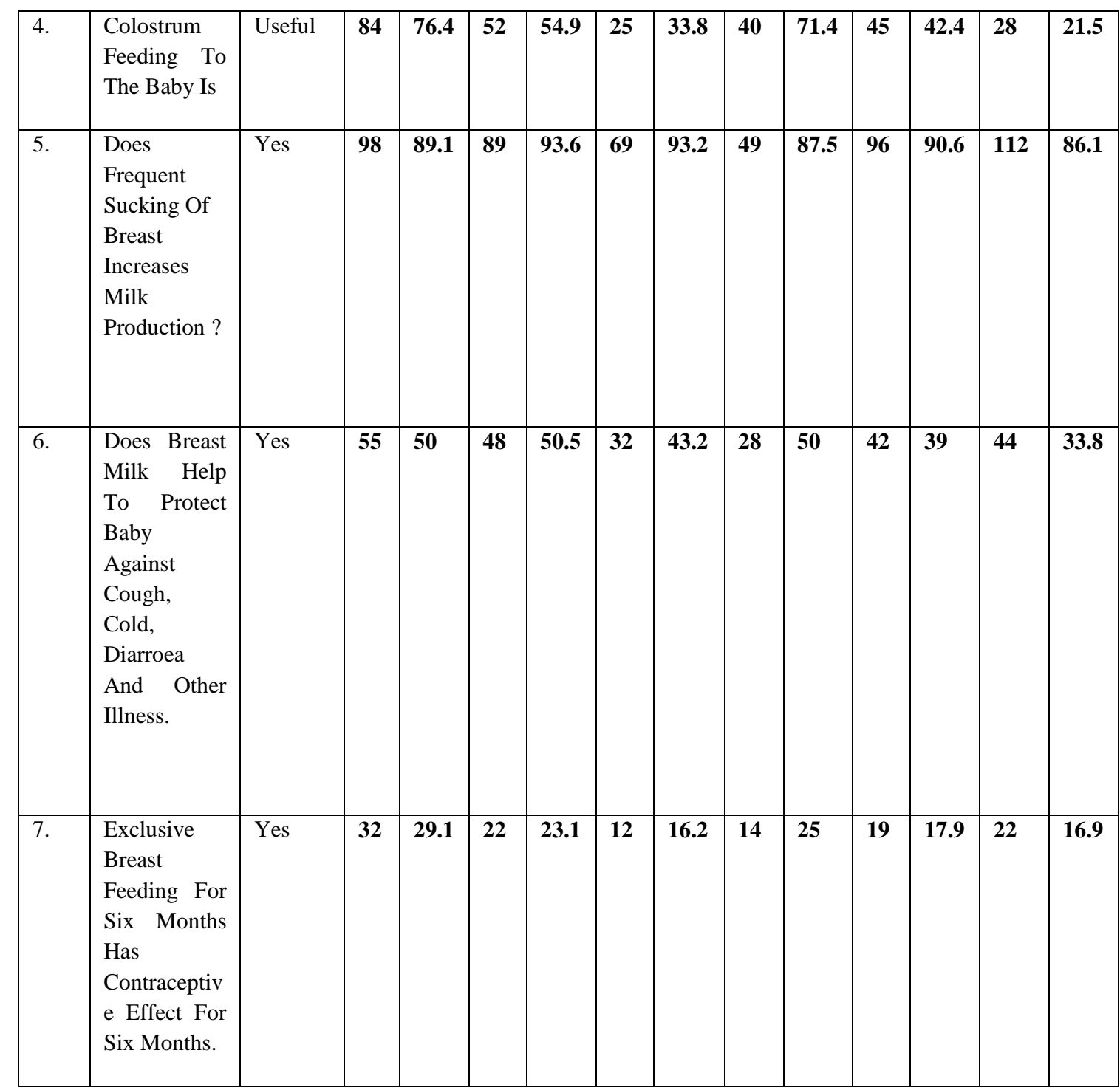

$\mathrm{N}=$ no of respondent

\section{Observation}

From the table it can be observed that a large section of educated (76.4\%) and about half (54.7\%) of literate in urban area were of the view that babies should be exclusively breast fed for six months but their rural counterpart were significantly less aware $(\mathrm{p}<0.05)$ about this fact.

The fact that breast feeding should be continued as long as possible, was also known among rural people, but surprisingly illiterate were more aware than educated woman. Educated and literate women of urban area were significantly less aware $(p<0.05)$ than their rural counterpart about the fact that breast feeding should be continued as long as possible. Majority of the educated women of urban and rural area were of the view that breast feeding should be immediately started after birth and colostrums should be fed to the babies as its useful for them, but notably the illiterate and even literate were least aware of the fact.

Both rural and urban women of Nalanda district were well known (about 90\%) of the fact that frequent sucking increases breast milk production. About half of the urban educated \& literate and rural educated knew that breast milk helps to protect babies against cough and cold, diarrhea and other illness, where as illiterate were less aware about it. Negligible respondent in both urban and rural area knew that exclusive breast feeding for 6 month has contraceptive effect till six month after delivery.

\section{Discussion}

There was significantly poor awareness among rural women in comparison to urban educated and literate regarding exclusive breast feeding till 6 months after birth. Urban women knew that after 5 to 6 months of birth food supplementation to the infant was necessary for better growth and development. In contrast, rural 
women continued breast feeding for longer periods and considered necessity of supplementary feeding at around one year of age or so as the digestive system of the baby being weak it could not tolerate and digest solid food during infancy.

The knowledge that breast feeding should be continued as long as possible and frequent sucking increases breast milk secretion was satisfactory among rural people especially among illiterates. Increased awareness among illiterate both in urban and rural may be due to prevalent breast feeding practices among them. Traditionally they breast feed their children for about 2 years or beyond (Sinha RKP etal1990) . Nursing mothers were generally motivated by mothers, grandmothers and other family members. Urban educated and literate mother on the other hand discontinued breast feeding quite early. In most cases either breast milk was not sufficient or due to cosmetic reason, urban mother stopped breast feeding early and preferred top feeding instead. Aggressive promotion of baby food by commercial industry also plays a vital role in giving preference to top feeding specially among educated and literate ladies. With increase in educational level and outdoor working of mothers there is decline in breast feeding practices (Wallia BNS1987). Prolonged breast feeding by rural ladies in comparison to urban was observed in other studies also (Dattal M.S. 1984,ICMR 1986) further more Walia BNS(1975), Idris MZ(1981) and Satpathy RK(1984) also observed prolonged breast feeding by mothers of low socio economic status of both rural and urban area.

Though awareness among educated women about colostrum feeding and starting breast feeding immediately after birth was better, it was generally poor among literate and illiterate of both urban and rural areas. Poor awareness of colostrums feeding may be attributed to misconception among some women that colostrums was useless or sometimes may do harm to the baby. Breast feeding is not initiated before $24 \mathrm{hrs}$ after birth in most cases and some time it is initiated after 48 to $72 \mathrm{hrs}$ due to fear that breast milk remains hot and harmful to the baby during the period. Some educated mothers started breast feeding after consultation with pandits in subh muhurat on particular (auspicious) day (Sinha RKP etal 1989). Such feeding practices were observed by Prasad RK etal (1976) in Delhi, Datta Banik ND (1975) in an urban study, Gupta MC etal (1980) from Gwaliar and ICMR (1980) from Pune. However, Dattal MS (1984) in Himachal Pradesh observed that colostrum was not considered harmful.

Although breast feeding was universal the protective value of milk against some diseases like cough, cold, diarrhea was known only to about $50 \%$ of the urban educated and literate along with rural educated whereas rural literate and illiterate generally were unaware of this fact. Breast milk in certain condition was considered to be aggravating diarrhea rather than preventing it.

\section{Summary And Conclusion}

The knowledge and practices in nutrition is acquired by a person through the observation of food belief and feeding practices prevalent in the family, community and by formal education in schools. Awareness in various aspects of breast feeding are poor particularly among illiterates and most of the literate in rural area due to wide spread illiteracy and superstitions.

Possible reasons for sub optimal breast feeding in Nalanda district are primarily due to lack of proper information to the mother, inadequate health support, inability of the health care providers to help mothers experiencing breast feeding difficulty, propaganda and promotion of commercial infant milk substitute and baby food products. Therefore, for creating awareness among illiterate and updating knowledge among literates and educated women health and nutrition education should be imparted by health and ICDS personnel. A training and orientation programme for health and paramedical staff like - A grade nurse, ANM, ASHA, MAMTA, health educator and counselor should be conducted in the periphery and hospital set up regarding appropriate breast feeding practices, advantages of breast milk and its protective value against infection, usefulness of colostrums and early introduction of solid food with continuation of breast feeding up to 2 yrs or beyond. Further by these trained staff individual and family health education regarding breast feeding will be imparted by interpersonal communication in consultation room of doctors or in health centre, outreach centre and at home of the people. Baby friendly hospital initiative to be taken and breast feeding corner to be setup in every district or referral hospital and counseling to the pregnant and lactating women to be done through trained staff in SNCU and maternity ward of the hospital .

For generating awareness in general public help of mass media of communication is to be taken. T.V., Radio and other audio visual aids, newspapers, magazine, film, banners, posters, wall writing, health exhibition etc can be important media for IEC regarding protecting, promoting and supporting appropriate breast feeding practices. 


\section{References}

[1]. Datta banik N.D. Breast feeding and weaning practices of preschool children in urban community in Delhi. Indpediatr.1975:12:569

[2]. Dattal MS. Feeding practices of infant and children in rural and urban areas a H.P. Ind Pediatr 1984:21:217

[3]. Gupta MC etal. A review of child rearing practices ..........at Gwaliar. Ind pediatr, 1980:17:261

[4]. Idris MZ etal. Feeding practices and diarrheal episode among rural and urban infants of Lucknow Ind pediatr, 1981:18:311

[5]. ICMR studies on weaning and supplementary food. Tech. report series no 27:1986

[6]. Dadhich, JP, Breast feeding, IAP text book of paediatrics $6^{\text {th }}$ Edition 2016:143

[7]. Park K. Feeding of infants. Park's text book of PSM 20 $0^{\text {th }}$ edition 2009:461

[8]. Prasad RK.A controlled study .................. Protein calorie malnutrition. Ind pediatr, 1976:13:169

[9]. Sinha RKP etal. An action oriented report on an ICDS block (Rural) in Patna District, NMCH Patna 1989

[10]. Satpathy RK. A community survey of infant feeding practices in Berhampur Orrisa. Ind Pediatr 1984:21:207

[11]. Wallia BNS. Decline in breast feeding practices in urban population of Chandigarh. Ind.Pediatr 1987:24(10):879

[12]. WHO and UNICEF. Global strategy for infant and young child feeding, 2015. 